\title{
Second home mobility in Finland: Patterns, practices and relations of leisure oriented mobile lifestyle
}

\author{
MERVI JOHANNA HILTUNEN AND ANTTI REHUNEN
}

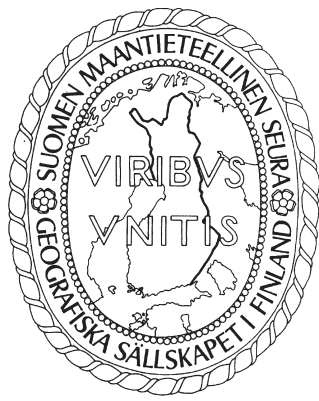

Hiltunen, Mervi Johanna \& Antti Rehunen (2014). Second home mobility in Finland: Patterns, practices and relations of leisure oriented mobile lifestyle. Fennia 192: 1, pp. 1-22. ISSN 1798-5617.

The paper focuses on leisure oriented mobile lifestyle between urban home and rural second home in Finland which is one of the world's leading countries in terms of second home ownership and tourism. Spatial patterns and social practices of physical mobility related to second home use are revealed by using triangulation of research methods and data. Analysis is based on GIS data, questionnaire survey results and national statistics. A relational approach is applied to conceptualise and contextualise second home mobility which is influenced by many bio-physical and socio-cultural processes and changes. Relational elements and processes interlinked to past, present and future of second home related physical mobility are identified. Natural amenities form the physical geographical basis for rural second home distribution which correlates with length of shoreline, distance to urban areas and local land use in second home environments. Second home related spatial mobility patterns differ and depend on size of the urban region of origin. Helsinki metropolitan dwellers have the longest trips to second homes which is explained not merely by environmental but by historical, societal and social reasons as well. Second home related social mobility practices are dependent on cottage owners' and users' life phase and standard of second homes. Retiring baby boom generation is the largest and most active cottager group and after retirement the use of second homes increases remarkably. The vast majority of second home owners and users travel the cottage trips by private cars and wish to spend at least as much time at rural second home as present. However, they do not intend to give up the urban home which leads to the conclusion that leisure related lifestyle mobility in between urban and rural living environments will continue to characterise second home owners' and users' way of life.

Keywords: rural second homes, mobile lifestyle, physical mobility, tourism geography, relational approach, Finland

Mervi Johanna Hiltunen, Centre for Tourism Studies, University of Eastern Finland, Savonlinna Campus, Kuninkaankartanonkatu 7, P.O.Box 86, Fl-57101 Savonlinna, Finland.E-mail: mervi.hiltunen@uef.fi

Antti Rehunen, Environmental Policy Centre, Finnish Environment Institute SYKE, Mechelininkatu 34a, P.O.Box 140, Fl-00251 Helsinki, Finland. E-mail: antti.rehunen@ymparisto.fi

\section{Introduction}

Increasing human mobility characterises daily life and leisure time in most societies in today's networked world. Human physical and virtual mobility plays such a central role in modern life that the notion of a mobile society has become an established discourse in the social sciences (Hall 2005; Cresswell 2006; Sheller \& Urry 2006; Urry 2007; Adey 2010; Cresswell et al. 2010). Human mobil- ity is tightly interconnected to immobility, places and dwelling, and ever more often everyday life consists of attachment to more than one place of residence. Dual or multiple dwelling and place attachment often results in frequent travelling between meaningful places. Such mobile ways of life and multilocality are related not only to social or occupational obligations but also to leisure and free time (Gustafson 2006; Bendix \& Löfgren 2007; Rolshoven 2007; Mclntyre 2009). 
A vivid example of contemporary mobile lifestyle is second home tourism (Hall \& Müller 2004a; Gallent et al. 2005; McIntyre et al. 2006; Roca 2013). Rural second homes belong to cultural tradition in many parts of the world and are a particularly common way of life in the Nordic countries (Tress 2002; Periäinen 2006; Müller 2007, 2013; Marjavaara 2008; Overvåg 2009a; Hall et al. 2009; Pitkänen 2011a; Nouza et al. 2013). The lifestyle of second home owners and users is characterised by routine based mobility between home and second home, quite often between the urban and the rural. As Müller and Hall (2004: 273) note "second homes indicate the development of new, more fluid patterns of mobility and place affiliation which rather than setting the rural and the urban as opposing categories, position them as part of an interrelated and networked whole". This paper exemplifies leisure oriented mobile lifestyle in Finland, where rural second homes are a lively part of cultural tradition (Vuori 1966; Periäinen 2006; Hiltunen 2009; Vepsäläinen \& Pitkänen 2010; Pitkänen 2011a). It is common in Finland and generally in the Nordic countries that rural second homes are not in reach of the elite only (Hall \& Müller 2004a; Halseth 2004) but have long belonged to the lifestyle of common people (Anttila 2008).

In human mobility at least five interdependent mobilities can be distinguished; physical travel, transportation, imaginative, virtual and communicative travel (Larsen et al. 2006; Urry 2007). This paper concentrates on physical (corporeal) human mobility which refers to individuals' travelling between places and implies the overcoming of spatial physical distance (Gustafson 2006). Mobility can be described as flows between places and within networks in time-space where movement is not simply occurring but actively producing multiple dynamic spaces and times (Massey 2005; Urry 2007; Merriman 2012). In second home tourism, the time-space is understood as the life sphere of second home owners and users in interaction and spatial continuum of urban and rural environments. The time-space of second home mobility constitutes of many relational social and material elements and processes which are identified and discussed in this paper. Mobility is here understood as 'socially produced motion' through observable, measurable and empirical reality on one the hand and practised, experienced and embodied on the other (Cresswell 2006: 3). Mobility thus occurs as a complexity of "socio-spatial relations between physical spaces, places of meaning and spatial patterning" (Healey 2007: 2).

Haldrup (2009) points out that the notions of second home and second home tourism are vague and fuzzy by nature and need to be contextually defined. Second homes vary from being purposely built weekend and vacation homes, cottages and cabins to permanent houses left vacant and even to semi-mobile caravans and boats. The term second home is here used for a privately owned rural recreational residence. The terms second home and cottage are used synonymously. In Finland rural second homes are most commonly wooden cottages located in the countryside, usually at shore sites in forest environments (Periäinen 2006; Nieminen 2010). By the end of the year 2012 there were 5.3 million dwellers in Finland, 2.9 million permanently occupied dwellings and nearly 0.5 million $(496,200)$ statistically counted second homes (OSF 2012a, 2013a). Approximately 15\% of households own a second home and nearly 800,000 Finns belong to second home owner households. It has been estimated that around three million Finns have access to a second home since many cottages are used by relatives and friends (Nieminen 2010). As a result of general wealth growth and new consumption patterns Finnish second home culture is currently changing from simple summer cottage life to the year round use of well-equipped second homes (Pitkänen \& Vepsäläinen 2008; Nieminen 2010; Pitkänen 2011a; Hiltunen et al. 2013).

In many countries, rural second homes are located in intensively used recreational areas of urban hinterlands that feature the agglomerations of cottages in amenity rich landscapes (Hall \& Müller 2004a). However, in Finland most second homes locate outside rural community centres or villages and do not form any clear settlement structure as such. The rural cottage landscape is therefore characterised by the dispersed spatial distribution of cottages spread in forest surroundings along the mosaic of natural water bodies (Pitkänen 2008), with only $14 \%$ of cottages located in rural villages (Vepsäläinen \& Rehunen 2009).

The late modern rural landscape is characterised by various functions, besides traditional agricultural and industrial production and residential housing, also by new forms of work, temporary housing and recreational consumption (Cloke 2006; Woods 2011). Second homes interact in between the housing and recreational functions 
of the rural and ever more often as places for distance work too.

The life and social identity of second home owners and users is constituted within the dynamic and blurring continuum and interaction between the urban and the rural. This paper aims at representing and analysing mobility patterns and practices related to rural second home tourism in Finland and opening up the interdependences of relational spatialities and temporalities of second home mobility.

\section{Research approach, framework and aims}

The paper contributes to relational understanding and conceptualisation of human physical mobility. In relational terms human mobility is here examined not only as spatial patterns of physical proximities, distances, and locations, but also as social practices, behavioural patterns and enactments in time-space. Moreover, in relational terms second home mobility patterns and practices are linked to various human and non-human, social and environmental processes and changes which are elucidated in the Finnish context.

The recent theoretical approach of relational geography inspires to study the spatialities and mobilities of everyday life on different scales. The relational approach has become popular in human geography and may be described as "an emphasis on the significance of networks, connections, flows and mobilities in constituting space and place and the social, economic, cultural and political forms and processes associated with them" (Woods 2011: 40). In relational spatial understanding space is imagined as the product of multiple interrelations and time-space as an open process of constant change (Thrift 2003; Massey 2005; Murdoch 2006). Interpreters of relationality and of human-environment relations consider spatialities as practices and processes where human and non-human, social and material actors and relations are engaged (Whatmore 2002; Hinchliffe 2007; Woods 2011). This paper emphasises that human mobility is always relational (Massey 2005; Adey 2010) and aims to conceptualise and analyse second home related physical mobility through the relational approach. The relational view to mobility would also involve understanding of lived experiences, perceptions, feelings and motives related to travelling these aspects, however, are left out of this paper's focus.
Second home mobility is here scrutinised through two interwoven aspects of mobility, namely spatial mobility patterns and social mobility practices which occur in the relational continuum of urban and rural living environments (Fig. 1). The two aspects of study help to form an analytical framework and contribute to comprehensive understanding of second home related physical mobility. When analysing spatial mobility patterns, attention is paid to the locations of primary and second homes, distribution of second homes, distances and routes between the homes, as well as the volumes and flows of second home mobility. Analysis of social mobility practices focuses on second home trips, the means of transport and travelling, use of second homes and access to rural second homes. The phenomenon of second home tourism and related mobility is in constant change, enabled and influenced by the elements and processes of surrounding bio-physical and socio-cultural environments. These elements and processes are identified and discussed as contextual interlinkages affecting the past development, present situation and future directions of second home mobility in Finland. The bio-physical environment encompasses natural and built environments, whereas socio-cultural environment comprises changes in the society, culture and social life of people.

The paper responds to the research questions of how second home related mobility is currently appearing and practised in Finland, and what relational elements and processes are intertwined with second home related mobility patterns and practices? These questions open up the processes and contexts behind the phenomenon and furthermore lead to discuss what are the future prospects of second home related mobility and mobile lifestyle in Finland.

\section{Research on second home spatialities and mobilities}

The theories and aspects of human geography have been applied widely in second home research and much of the research has been done under the rubric of tourism geography (Butler 2004; Hall \& Page 2006; Haldrup 2009; Müller \& Hoogendoorn 2013). Second home tourism related mobility has, in recent literature, predominantly been researched from the viewpoint of spatial and regional patterns of second homes whereas 


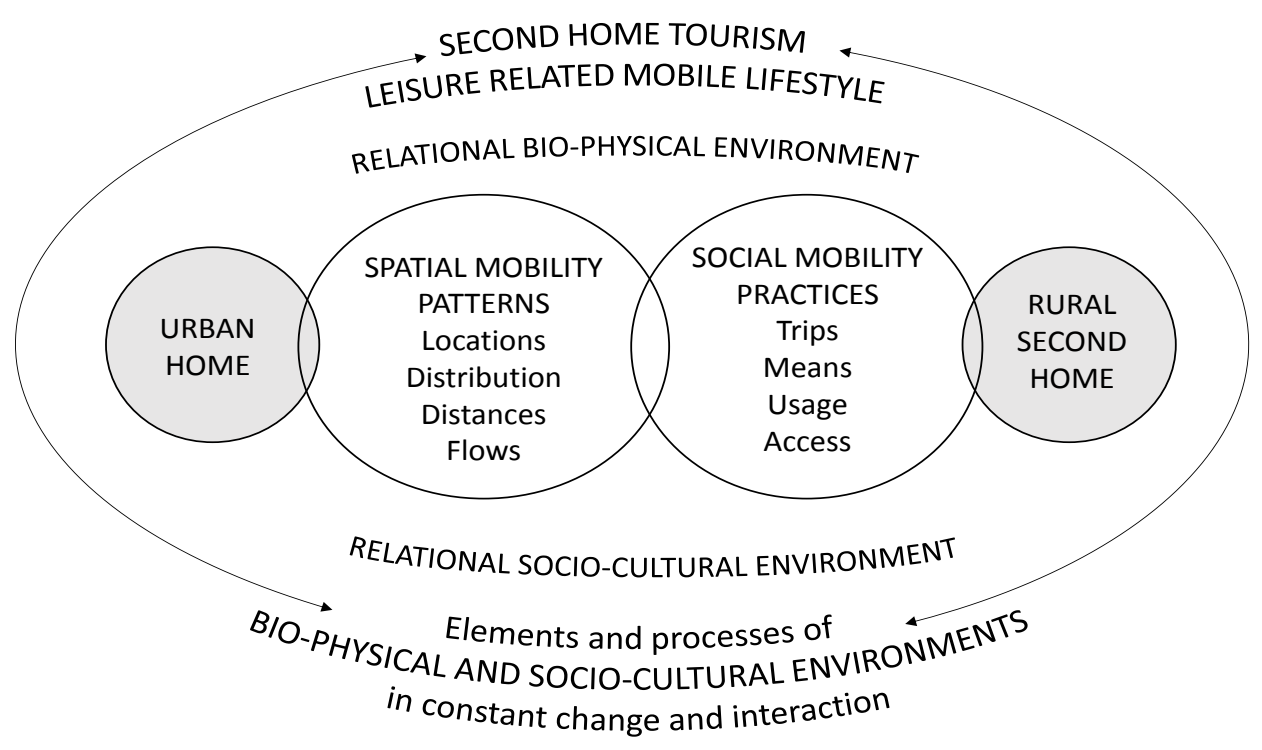

Fig. 1. Research frame of spatial mobility patterns and social mobility practices of second home tourism in the interaction of urban and rural living environments. Relational time-space of second home tourism is constantly influenced by changes and processes in bio-physical and socio-cultural environments.

the behavioural patterns and mobility practices have got less attention (e.g. Müller et al. 2010). Second home tourism related spatial mobility patterns and travel flows are dependent on many geographical factors and processes. Müller (2006) and Hall and Müller (2004b) refer to the classic geographical distance decay effect influencing regional patterns of second home tourism. Accordingly, cultural or spatial interaction between two places declines as the distance in between increases ( $\mathrm{Pi}$ rie 2009). Second homes mainly concentrate in the amenity rich hinterlands of population centres and majority of second home owners live close to their second homes. However, alongside increasing human mobility and improvements in transport technology, diminution due to distance has become relative and relational (Pirie 2009). Distribution of second homes around urban centres does not necessarily follow law like patterns and stiff spatial models. Overvåg (2009b) notes that second home spatial structure may vary locally a lot due to urban growth, location of amenity rich regions and availability of recreational attractions nearby. Tjørve et al. (2013) observed that social preferences and place attachment may override the long distance and travel time to rural second homes. Furthermore this 'belonging effect' seems to persist and pass on to the next second home owner generations. In the case of Finnish Lakeland Pitkänen (2008) showed that rural roots, kinship and cottage inheritance affect second home locations and distribution. Müller (2004, 2006) points out that even though second home tourism is a very regional form of tourism and most second homes are located within the weekend leisure space, there are also highly attractive areas, "hot spots" in mountain and coastal regions attracting second home owners from further distances. Moreover, the current trends of second home tourism include purchasing of multiple second homes in divergent locations, not just in domestic ground but increasingly transnational too (Haldrup 2009; Paris 2010).

As Müller (2006) and Hall and Müller (2004b) note, second home spatial patterns are also influenced by population distribution and change, industrialisation and urbanisation, and such primary economic determinants as space-time accessibili- 
ty (time budget), income level and real estate costs. Overvåg (2009b) states that social and societal changes such as increasing wealth, car ownership, new recreational interests and outdoor activities as well as building up of road and transport network all affect the distribution of rural second homes. Furthermore, second home spatial development is affected by building regulations and environmental planning guidelines, and other land use in the region including existing rural housing stock, agricultural land and forests (Overvåg 2009b). Shellito (2006) identified destinationbased geographical characteristics affecting second home distribution in the US Great Lakes States and concluded that the presence of natural areas and water bodies play the most dominant role in rural second home distribution. Also second home locations are dependent on distance from large and small urban centres, and accessibility by local roads (Shellito 2006). Müller (2007) notes that second home ownership, as a cultural and geographical phenomenon, is nowhere in the world as extensive and widespread as it is in the Nordic countries. Around half of the population in Finland, Sweden, Norway and Denmark has access to second homes (Müller 2007). When it comes to usage rate the countries generally display an active pattern; Finland reports that second homes are used on average 75 days, Sweden 71 days and Norway 47 days a year (Lithander et al. 2012).

\section{Multiple research methods and materials}

This paper analyses the spatial mobility patterns of Finnish second home tourism and provides an insight to the social mobility practices of second home owner and user households. Multiple research methods and research triangulation are used and diverse data with regard to time, space and scale analysed. Also researcher triangulation is used to gain more knowledge and expertise as well as result cross-check (Creswell 2003; Eriksson \& Kovalainen 2008). As background information key statistics and the national survey results on recent changes in Finnish second home tourism are reviewed. Second home related spatial mobility patterns are analysed based on national GIS data and the scope is narrowed down to questionnaire survey analysis on mobility practices of second home owners and users. The use of multiple and complementing research methods and data results in deeper and wider understanding on physical mobility patterns and behavioural practices of second home mobility. Research findings are interpreted and contextualised through the relational approach of human geography which furthermore deepens understanding of the researched phenomenon. The linkages and relations of environmental, societal and social development processes to second home tourism and mobility are drawn.

The spatial patterns of second home regional development and mobility are illustrated through GIS data produced and maintained by Finnish Environment Institute SYKE. The GIS data includes all second homes in Finland, their location, qualities, and owners' place of residence. Geographic datasets allow to analyse and illustrate the dynamics of second home development and mobility. In this paper, the direct distance between second home owners' permanent and second home was calculated from the location data. Second home environments and transport connections were studied with the help of a wide range of geographic datasets on natural environment, land use and road network in the whole of Finland. The vector and raster analysis tools of GIS software ArcGIS 9.3 were used to join datasets together and to study the second home mobility on road network.

Rural and urban areas were identified according to GIS-based classification developed by SYKE and University of Oulu (Helminen et al. 2013). The classification distinguishes different categories within the urban-rural continuum on the basis of building density, population, accessibility, commuting, land use intensity, and employment. Urban areas in this paper are defined to include the core urban areas of the classification. They are population centres with more than 15,000 inhabitants and with building density that implies detailed land use planning. Rural areas, in the broadest aspect, comprise all areas outside the urban areas. The urban fringe is located between urban and rural areas and characterised by mixed land use. Although it is often associated with urban areas, in terms of second home density, the urban fringe zone is similar to rural areas. Geographical distance is here defined as physical distance between places, sites and locations. In mapping of spatial mobility patterns, distance is measured in absolute terms. Whereas in describing social mobility practices, distance is understood in relative terms, involving travel in outdoor spaces, and implying to travel time and length of the route or 
journey. The distance is thus relative to route, mode of transport, time and costs of travelling ( $\mathrm{Pi}$ rie 2009).

Besides GIS analysis, the paper presents results of a recent questionnaire survey. The authors were involved in a researcher team who planned and conducted a postal survey on multiple dwelling and second home use in Finland. Homes beyond Homes Study ( $\mathrm{HbH}$ Study) was a questionnaire survey carried out in October and November 2012 and addressed to randomly selected 15-84-yearold citizens living in Finland and the autonomous Åland Islands. Sample size was 4,000 and with one reminder round the response rate reached $29.7 \%$ (N 1189). The recipient addresses were obtained from the Finnish Population Register Centre VRK. The structured survey data has been quantitatively analysed with the SPSS software and cross tabulations presented here statistically tested (chisquare $X^{2}$ test) and found significant $(p<0.05)$.

In the following sections spatial mobility patterns related to Finnish second home tourism and mobility are analysed based on GIS data. Attention is paid to the spatial distribution and locations of rural second homes and to travel distances and flows between permanent and second home. The questionnaire survey results are then analysed and social mobility practices concerning households' travelling to second homes, the overnights, the means of travelling and weekend mobility exposed. Survey results on distance work done at second home and commuting from second home are also touched upon. Finally, the future of second home related mobility is discussed.

\section{The spatial mobility patterns of second home tourism in Finland}

Physical human mobility related to second homes has evolved alongside the cultural history of second home tourism in Finland, having similarities to Scandinavian and North American second home traditions (Löfgren 1999; Müller 2007; Haldrup 2009). During the mid-1900s, as second home tourism actually emerged among the lay people, the trips to summer cottages were often made by bus or train (Krohn 1991; Anttila 2008). These modes of transport were soon displaced by private cars as car ownership spread through the wider population.
Second home tourism in Finland intensified after the war time in the 1950s and especially during the decades of 1960s and 1970s as a consequence of rural out-migration and immensely rapid urbanisation. Rise in income levels, new legislation on working hours, increase in leisure time and car ownership, as well as improvements in the traffic system enabled ever more urban dwellers to purchase a rural cottage (Anttila 2008; Haldrup 2009). In many sparsely populated areas, there was plenty of suitable and cheap land available at attractive shore sites. More and more lay people with roots in the countryside could build up cottages often on family land (Anttila 2008). Still, in the 1950s and 1960s, travelling to second home could be once in a summer experience, and it was quite usual that families would spend the whole summer holiday in the country (cf. Bendix \& Löfgren 2007). Second home mobility today however is characterised by frequent motorised travelling between home and second home, especially on weekends and holidays.

\section{The spatial distribution and locations of rural second homes}

Finland is a sparsely populated country and rural cottage building at shorelines has been widespread and second home regional development relatively free from tight planning regulations. The peak in cottage building was experienced in the 1980s and still in the 1990s some 8,000 new second homes were built annually. The construction of new second homes has been gradually falling ever since yet around 3,500 new second homes are still built each year (OSF 2013a). Shoreline house building used to be fairly liberal and community based however planning regulations have gotten stricter along with the extensive growth of second home stock during the past decades (Ministry of Environment 2005). The tightening of land use planning legislation and environmental protection measures are the key tools for the environmental governance of second home development.

Societal changes, historical events and political actions have also influenced second home spatial distribution in rural regions. An example of a massive national political action is the Housing Act for the resettlement of 450,000 wartime veterans and Finnish evacuees from Russian Karelia to Finland at the end of the 1940s (Virtanen 2006). More recently, this has affected second home tourism 
since many of the former resettlement plots and small holdings built in rural scattered areas during the 1940s and 1950s are today used as second homes. During the 1960s and 1970s rural areas were affected by structural changes in agricultural production that together with industrialisation, automation and development of a service society contributed to rural regional decline and rapid urbanisation. Many of the new urban dwellers wanted to build cottages close to relatives back in the former home areas, and rural second home tourism got ever more popular. Still today population in Finland continues to concentrate in urban centres and the growing urban fringe areas. Rural areas are still declining in many parts of the country and second home tourism is expected to bring livelihood to rural municipalities at least seasonally (Rehunen et al. 2012). As most Finns live in urban population centres it is clear that the large number and distribution of rural second homes result in second home mobility between urban and rural living environments (Table 1 ).

In addition to societal changes different cultural traditions and national character of people influence second home spatial development and related mobility. The Finns typically look for solitude surroundings for rural second housing and cottages are traditionally built as far from neighbouring cottages as possible. In the most popular second home region, the Finnish Lakeland, second home owners were asked to estimate the approximate distance to the neighbouring cottage or house which was on average $370 \mathrm{~m}$ (mean) and typically 200 m (median) (Hiltunen 2005). Consequently, the aspiration for privacy and tranquillity has led to the dispersed spatial structure of secluded second home plots in rural areas.

Landscape, climate and natural amenities form the basis for the environmental attractiveness and regional distribution of rural second homes, affecting also mobility patterns. As figure 2 shows the spatial distribution of second homes follows well the major five geographical landscape regions of 1) Southern Finland and Archipelago, 2) Lake Finland, 3) Ostrobothnia, 4) Vaara Finland and 5) Lapland (Granö 1929; Raivo 2002). Similarly, second home distribution follows the major tourism regions of Finland; 1) Cultural Region, 2) Lake Region, 3) Ostrobothnia, 4) Wooded-Hill Region and 5) Lapland (Vuoristo \& Vesterinen 2009). Second home regional distribution covers thus both nature based and cultural tourism regions (Leinonen et al. 2007). The amenity rich landscapes of second homes concentrate in the Lakeland in mid-eastern Finland, the Baltic seashore and archipelago in western parts of the country, and the tourism centres in the wooded hill and mountain regions of Vaara Finland and Lapland. It is also noticeable that in the Ostrobothnian low inland where agricultural land prevails and cottage distribution is low, the cottages are significantly more concentrated at watersides, around the few lakes and along the coastline and rivers leading to the Baltic Sea. According to the GIS data the length of shore-

Table 1. Distribution of population (in primary homes) and second homes in years 2000 and 2012 in different types of rural and urban areas based on the classification developed by SYKE and University of Oulu. Sources: SYKE; Helminen et al. 2013; Population Register Centre/Population Information System 4/2001, 4/2013.

\begin{tabular}{llrrrr}
\hline \multirow{2}{*}{ General area category } & & \multicolumn{3}{c}{ Population \% } & \multicolumn{2}{r}{ Second homes \% } \\
\cline { 2 - 6 } & Type of area & Year & Year & Year & Year \\
& & 2000 & 2012 & 2000 & 2012 \\
\hline \multirow{2}{*}{ Core urban areas } & Inner urban areas & 30.9 & 31.7 & 0.1 & 0.1 \\
& Outer urban areas & 25.2 & 26.5 & 0.9 & 0.3 \\
\hline \multirow{2}{*}{$\begin{array}{l}\text { Urban-rural transition } \\
\text { zone }\end{array}$} & Peri-urban areas & 9.9 & 10.9 & 8.8 & 8.2 \\
& Rural areas close to urban & & & & \\
& areas & 7.3 & 7.4 & 25.9 & 25.5 \\
\hline \multirow{3}{*}{ Rural areas } & Local centres in rural areas & 6.4 & 6.1 & 0.3 & 0.7 \\
& $\begin{array}{l}\text { Rural heartland areas } \\
\text { Sparsely populated rural } \\
\text { areas }\end{array}$ & 13.1 & 11.7 & 23.8 & 23.5 \\
& & 7.1 & 5.8 & 40.2 & 41.8 \\
\hline
\end{tabular}


line explains the areal distribution and density of second homes in Finland better than any other environmental factor.

In addition to natural amenities and landscape characteristics land use and especially population agglomerations also affect the location of second homes and related mobility patterns. Most dense concentrations of second homes are found within the distance of a weekend trip from Helsinki or day trip from smaller urban centres. Furthermore, the GIS data shows that second home density correlates with rural land use on local level, with real estate size, density of permanent population and agricultural land use. It is noticeable that in many rural areas second homes form the predominant land use compared to permanent housing (Fig. 3). Second homes in Finland expand rural populated areas and increase the use of roads and shorelines. According to the GIS data the number of populated $1 \mathrm{~km}^{2}$ squares is $50 \%$ higher when also second homes are considered. Outside population centres, trips to second homes increase the total length of roads used in everyday mobility by $50 \%$. The length of developed shoreline due to second homes is approximately double the length used by permanent homes.

Built and natural environments of second home surroundings were examined in the $\mathrm{HbH}$ Study (Table 2). Accordingly most second homes locate in rural scattered areas, only every sixth in a rural

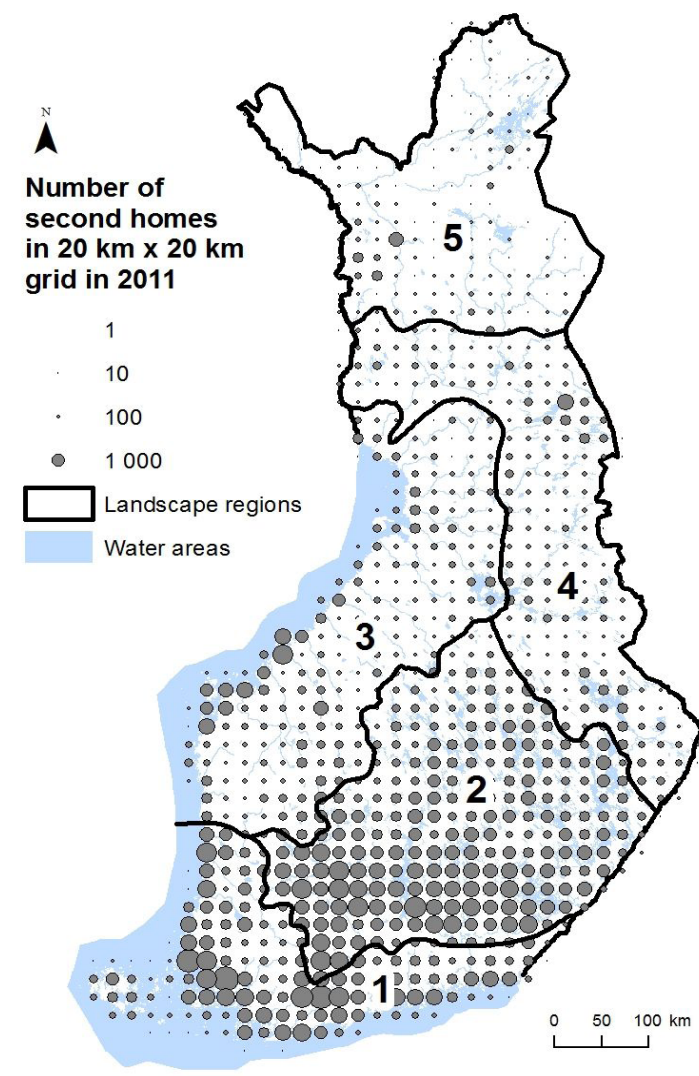

Fig. 2. Spatial distribution of second homes in Finland follows well the major geographical landscape regions of 1) Southern Finland and Archipelago, 2) Lake Finland, 3) Ostrobothnia, 4) Vaara Finland and 5) Lapland. Sources: Raivo 2002, Population Register Centre/Population Information System 4/2012; SYKE C.

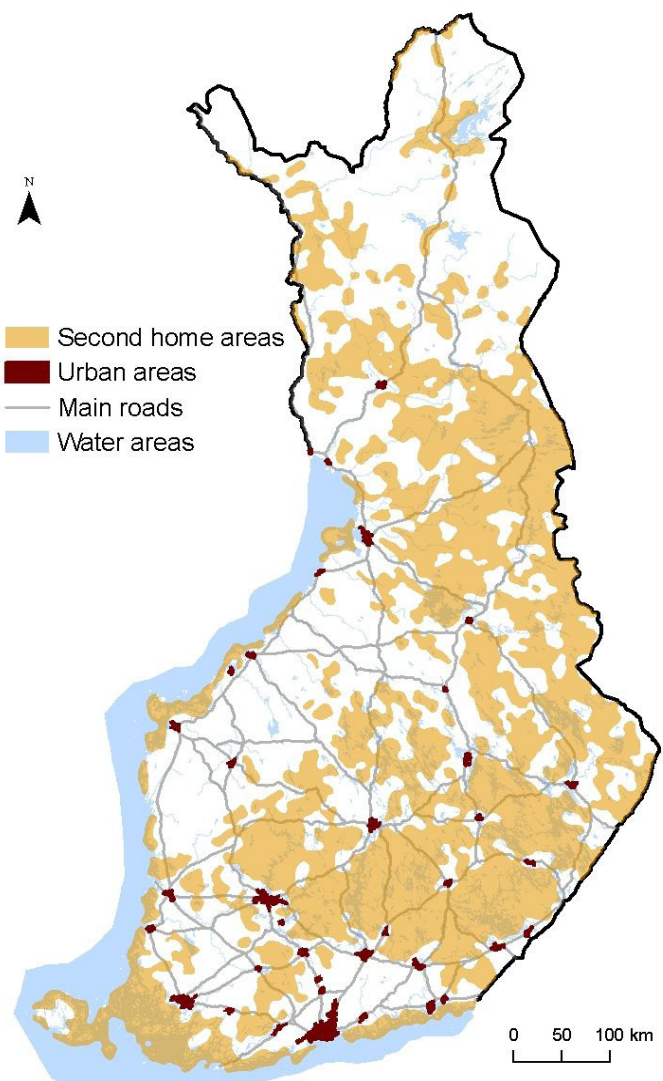

Fig. 3. Areas of rural Finland where second homes are more predominant form of land use than permanent housing. Sources: Population Register Centre/Population Information System 4/2012; SYKE C. 
Table 2. Features of built and natural environments in rural second home surroundings. Source: HbH Study 2012 (N 649).

\begin{tabular}{lclc}
\hline Built Environment & $\%$ & Natural Environment & $\%$ \\
\hline Rural scattered area & 75.0 & Forest & 71.6 \\
Rural village & 15.1 & Field & 23.4 \\
Cottage village & 6.3 & Shoreline & 66.9 \\
Tourism centre & 3.3 & Island & 19.4 \\
Urban surrounding & 5.6 & Fell or mountain & 3.8 \\
& & Wilderness & 3.4 \\
\hline
\end{tabular}

village and hardly any in urban surroundings. Many new second homes nowadays locate in purpose built cottage villages and tourism centres with normal municipal engineering systems, including street lighting. Natural environment around second homes is most often forest and quite often cottages locate in agricultural and field surroundings. Very often the location is at lake, sea or river shoreline or on island. Water bodies and forests are thus the main natural elements around rural second homes. In a minority of cases the surroundings are fell, mountain, and wilderness.

\section{Travel distances and flows to rural second homes}

The spatial distribution of second homes in relation to second home owners' place of residence explains well the physical mobility patterns between permanent and second home. According to the GIS data the direct (absolute) distance between home and second home in Finland was on average $93 \mathrm{~km}$ (mean) and typically $39 \mathrm{~km}$ (median) in 2011. The actual (relative) distance along roads is usually approximately one-third longer. Direct distances have grown more than 10\% between 2004 and 2011. In figure 4 average distances to second homes are presented among all Finnish second home owners of private households, according to municipality of owner's permanent residence. The distances to second homes differ depending on the population size and density of the urban region of origin. Those second home owners who live in the metropolitan region of Helsinki have two to three times longer distances to second homes compared to second home owners of major provincial cities. National Travel Survey data (HLT 2012) also affirms that the Helsinki urban region inhabitants make a lot more long trips to summer cottages than the rest of the population. This is not just the congested metropolitan green belt which leads to longer distances, but also geographical, societal and cultural reasons mentioned earlier have influenced the development.

As figure 4 illustrates the distance between urban home and rural second home is lowest for second home owner households living in small provincial urban centres located in amenity rich regions of Lakeland and western coastal areas. Whereas the urban-rural distance is longest for

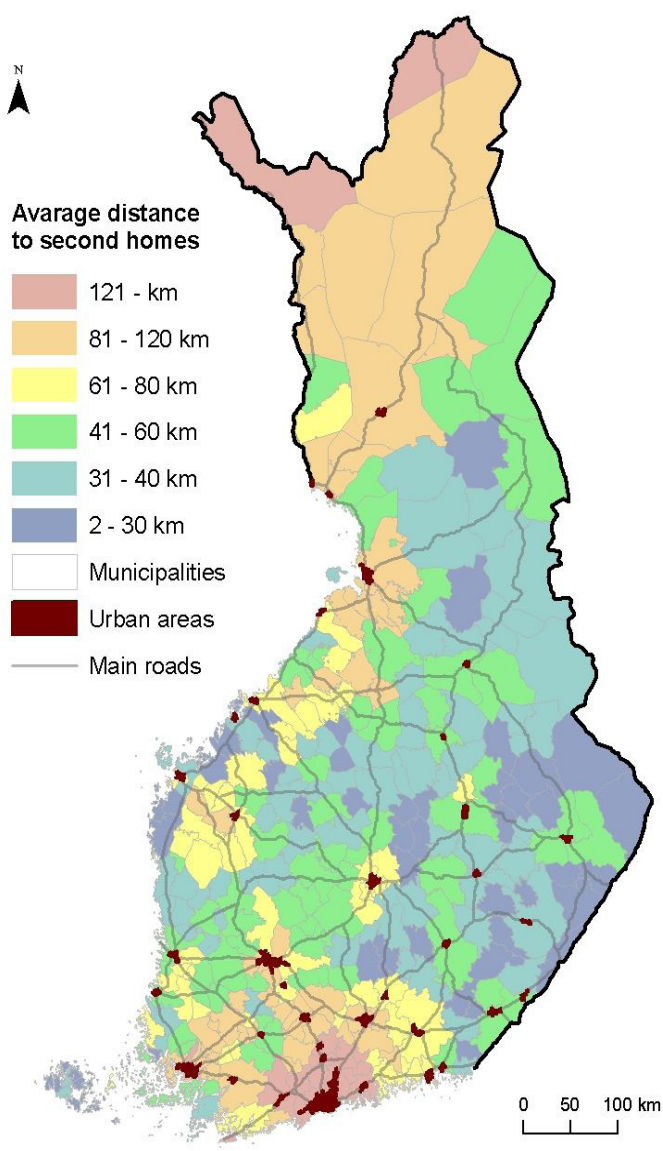

Fig. 4. Average direct distance between home and second home according to second home owner's municipality of permanent residence. Sources: Population Register Centre/ Population Information System 4/2012; SYKE C. 
households living in the large and densely populated urban regions of southern Finland. Paradoxically, the distance to second home is highest for dwellers in two totally dissimilar regions namely in the congested metropolitan region in southernmost Finland and in the very remote areas of northernmost Lapland. When comparing urban centres, the basic pattern of distance decay applies to most urban regions however differs clearly in the capital region of Helsinki and city of Oulu (Fig. 5). Oulu is the major industrial and technological urban centre in northern Finland and has gathered employees from remote rural areas. Former farmhouses and residential buildings in rural villages
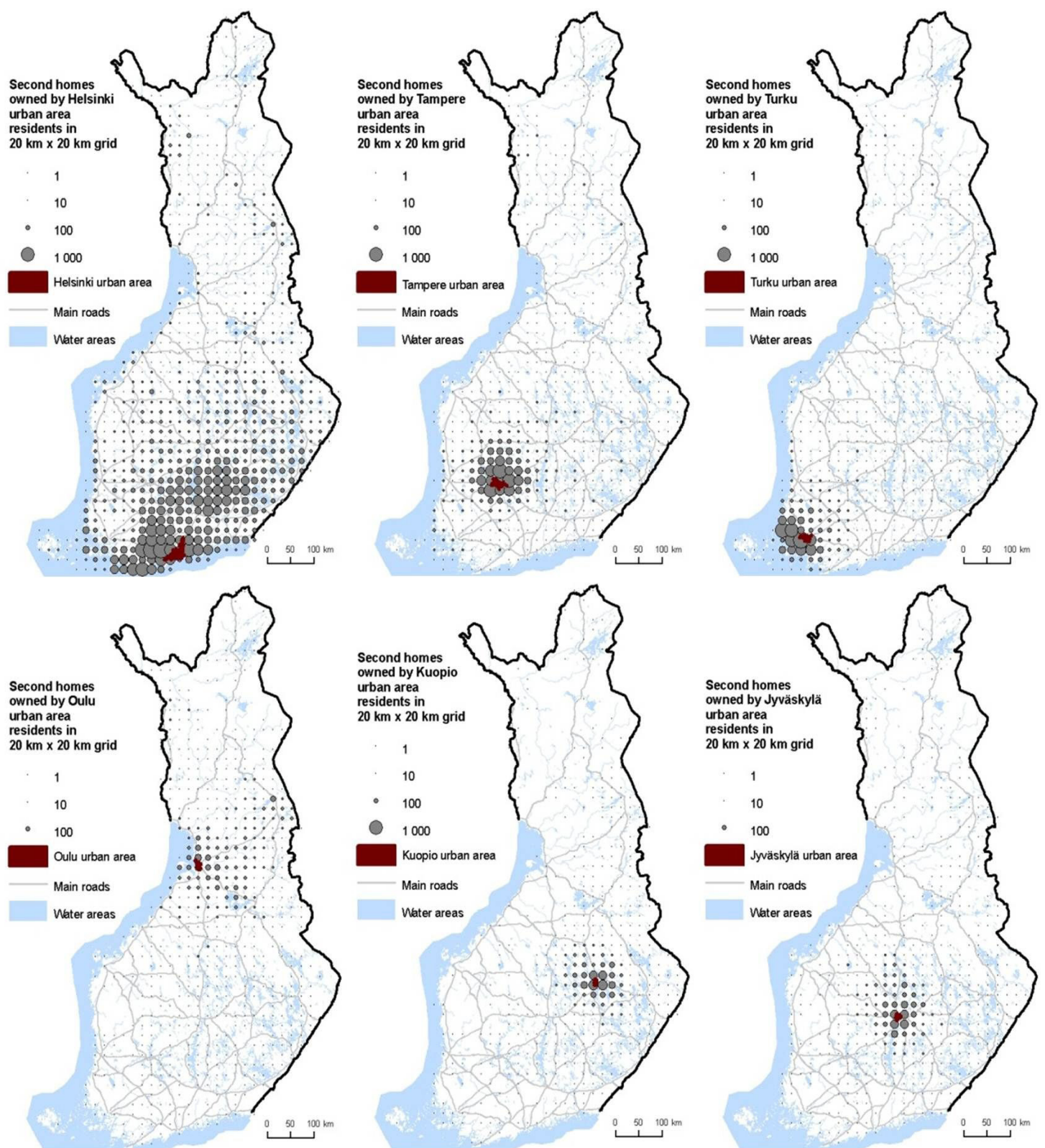

Fig. 5. Second home distribution in relation to cottage owner's permanent residence in Helsinki metropolitan area and major provincial urban centres. Sources: Population Register Centre/Population Information System 4/2012; SYKE (C). 
are often used as second homes. The large Lake Oulujärvi clearly attracts second home owners in a region which otherwise has few lakes. Second homes and time shares are also purchased in the skiing resorts of Lapland and Wooded-Hill Region. The largest second home mobility volumes flow from Helsinki metropolitan area along the road network to rural Finland (Fig. 6). The GIS data indicates that second home owners living in Helsinki area own $21 \%$ of all second homes in Finland, but their combined distance kilometres represent $40 \%$ of total kilometres travelled from permanent to second home in the whole country. The metropolitan mobility flow heading towards Lakeland illustrates well the significance of natural amenities to second home regional distribution.

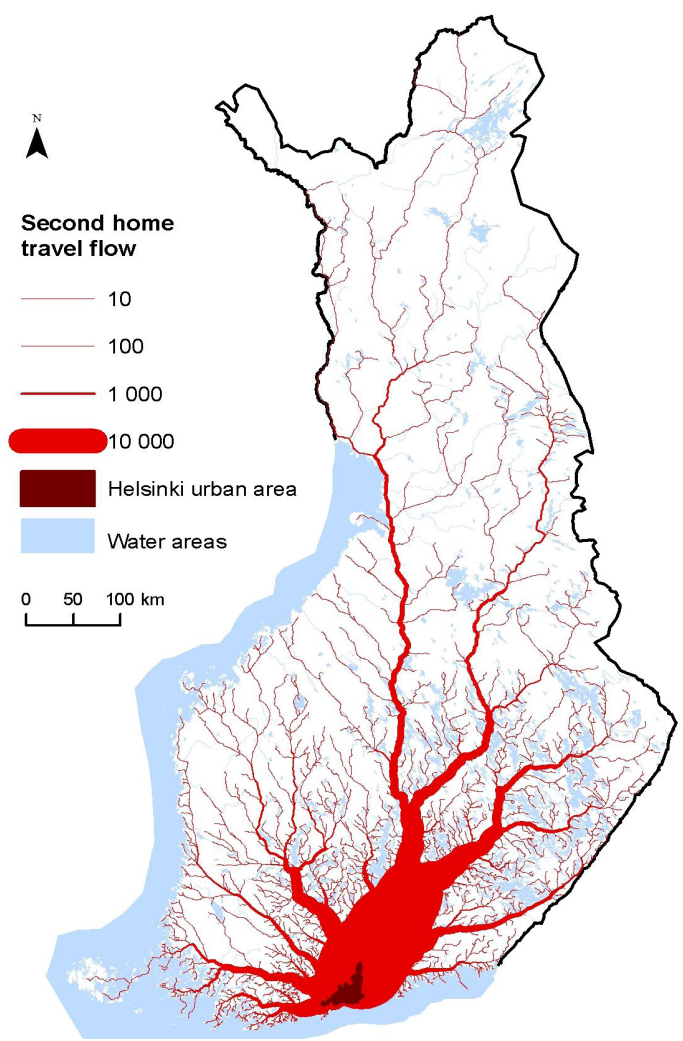

Fig. 6. The major second home travel flow in Finland heading from Helsinki metropolitan area along the road network to rural Finland, main direction to Lakeland. The travel flow is determined according to shortest time distance. Sources: Population Register Centre/Population Information System 4/2012; Finnish Transport Agency/Digiroad 2010, SYKE @ .
Second home tourism in Finland is particularly a phenomenon of motorised urban-rural mobility and dependent on accessibility to rural areas. Rural accessibility depends upon the development of transport system including the road network, standard of road building and year round management of roads. Second home owners and users use the whole road network from urban streets to motorways, from land and local roads to private gravelled roads leading to cottages. In a Nordic country like Finland, where the yearly four seasons range from hot summer periods to winter frosts, road management is challenging and road damages frequent. The main road network is managed by the state and regional government but small private gravelled roads are often in poor condition especially during the frost heave in springtime which may affect cottage accessibility. Due to their remote location second homes in Finland are best accessible by private cars which makes car ownership a self-evidence for second home owner and user households.

\section{Social mobility practices related to second home tourism in Finland}

Second home related mobility is scrutinised next from the perspectives of households and different social groups. As Hall and Page (2006) note second home ownership and use are related to broader travel and lifestyle behaviour and need to be seen within the wider framework of human mobility over the human life course. Second home owners' and users' life phases, rural roots, consumption patterns, duties in everyday life as well as socio-economic background all affect second home mobility. A closer look at mobility practices of Finnish second home owners and users is taken through $\mathrm{HbH}$ Study 2012 results (N 1189, response rate $29.7 \%$ ). The non-response analysis based on official statistics of Finnish population shows that the survey is representative in terms of location of permanent dwelling (province) and mother tongue (Finnish or Swedish). Second home owners were overrepresented $(+7.7 \%)$ and overrepresentation was respectively among female respondents, older age groups, people with low income (retired 
households), households without kids and people living in detached houses and owneroccupied dwellings. Underrepresented were young age groups, families with underage children and people living in rental dwellings and blocks of flats.

In this paper only those survey respondents who have access to privately owned domestic second homes at least once a year are discussed. These respondents were 54\% (N 649) of all survey respondents and include both the second home owners (35\%) and the second home users $(18 \%)$ who do not own a second home themselves but have a regular access to one. Female second home owners and users answered the survey more actively (55\%) than males (45\%). The average age of second home owners was 60 years whereas the users were a generation younger, at the age of 40 on average. Over half ( $55 \%$ ) of the second home owners and users were employed, one third (33\%) pensioners, $8 \%$ students and 3\% unemployed. Most second home owner and user households consisted of two adults (73\%) and one fourth $(25 \%)$ of the families had under aged children. The total gross income level of second home owner and user households was typically between 40,000 to 69,999 euro which is above the Finnish national average of 36,500 euro (OSF 2013b). The second home owner respondents thus represent typical Finnish second home owners who are middle aged couples, relatively wealthy, live permanently in urban surroundings and have roots in the countryside (Nieminen 2010). These same features characterise second home owner households in all Nordic countries (Lithander et al. 2012). A comparative study to $\mathrm{HbH}$ Study was conducted among Swedish second home owners (Müller et al. 2010) and will be discussed at the end of this section. However, the $\mathrm{HbH}$ Study provides a broader picture of second home tourism and mobility as both the owners and the regular users of second homes are analysed.

\section{Rural roots and rising living standard}

According to the $\mathrm{HbH}$ Study 2012 nearly all $(96 \%)$ second home owners and users had childhood and youth experiences in the countryside and quite many $(61 \%)$ had also lived in rural surroundings in earlier life phases. It was also note- worthy that second home life was familiar for slightly over half (54\%) of the respondents already from childhood and youth which indicates that second home related mobile lifestyle goes often within the family and over generations. One could presume that second home owners and users look for a housing form and environment quite different from the permanent one. Nevertheless nearly two-thirds of the respondents lived permanently either in detached houses $(47 \%)$ or semi-detached and row houses (18\%) whereas one-third (34\%) live in apartment flats. Furthermore, the floor space of permanent home was relatively high, typically $100 \mathrm{~m}^{2}$ (median). The second home building was in majority of cases purposely built cottage. Some $9 \%$ of second homes were houses left vacant in a household's possession, e.g. former farmhouses. In minor cases (1-2\%) the second home was a time-share, apartment, long term rental cottage, non-mobile caravan or allotment garden cottage.

Along with the overall rise in living standard the standard of equipment in second homes also keeps on rising. A similar trend seems to prevail in all developed countries with second home tourism (Haldrup 2009). Standard of equipment affects the use of second home and influences the number of visits and length of stays. The more modern amenities and facilities at second home the more it is used. According to $\mathrm{HbH}$ Study the average floor space in second home was $66 \mathrm{~m}^{2}$ (mean) and typically $50 \mathrm{~m}^{2}$ (median). Wired electricity was in most $(87 \%)$ second homes but also solar, wind or other electricity was used $(14 \%)$. Water closet was in one third $(30 \%)$ of second homes while typically cottages still have composting earth closets. Television was very common $(78 \%)$ and in every fifth $(20 \%)$ second home a dishwasher was available. Internet connection was in every fourth $(26 \%)$ second home. Over half ( $55 \%$ ) of respondents stated their second home is winterised and thus fit for year round use. It becomes ever more common that standards of the permanent home and second home converge (cf. Müller et al. 2010).

\section{Trips to and overnights at the second home}

According to national statistics, Finns made 5.9 million trips to own second home in 2011 which is $19 \%$ of all domestic free time trips (OSF 2012b). The amount of trips made to own second home 
has almost doubled during the past decade. Weekend trips have been rising considerably whereas the number of long trips with four or more overnights has increased more gradually (Fig. 7). There seems to be two major reasons behind the increase of second home trips. On one hand leisure time is increasing among the most active cottager group of currently retiring baby boomers born in the turn of the 1940s and 1950s. On the other hand standard of second homes is rising which positively affects the usage rate of second homes.

According to the $\mathrm{HbH}$ Study, the owners and users of second homes annually made on average 26 trips (median 15 trips) to the second home and stayed 50 nights (median 32 nights). The average distance between home and second home was 149 $\mathrm{km}$ (mean) but the distance varies a lot and a typical cottage trip was $75 \mathrm{~km}$ (median). For a fifth (19\%) of the respondents cottage trip was less than $25 \mathrm{~km}$. The average time spent on second home trip was two hours and 10 minutes (mean), but typically less than one hour and 10 minutes (median). There are notable differences in trips and overnights among the different user groups. Regular users make trips to and overnight in second homes over half a less during a year than second home owners. The owners make on average 32 trips and overnight 61 nights a year whereas the users make 14 trips and overnight 26 nights a year at second home.

The warm and light summer months from May to September are the most popular season for second home tourism with the peak in holiday month of July (Fig. 8). The number of trips made to second homes increases remarkably during the summer months yet relatively much more increases the number of overnights. People thus stay longer periods of time per visit at second home during the summer holidays. Another peak, though smaller, in cottage use is in December indicating the importance of Christmas holidays which are often spent at the cottage with family and friends. This trend also highlights the growing interest for year round use of second homes.

Retired second home owners and users are a growing user group of cottages. According to the $\mathrm{HbH}$ Study the retired respondents made 31 trips compared to working respondents' 24 trips to second home yearly. Furthermore, retired respondents spent on average 75 nights whereas the working respondents 40 nights a year in second home. It is obvious that after retirement second home owners and users are able to make more trips and spend more time at second home than if still working. According to this study retired respondents made almost one third (29\%) more trips and stayed nearly double $(88 \%)$ as much nights at the second home than employed respondents. Eventually ageing of retired second home owners and users may result in fewer trips to second homes due to inabilities in maintaining the cottage and willingness to drive long distances by car.

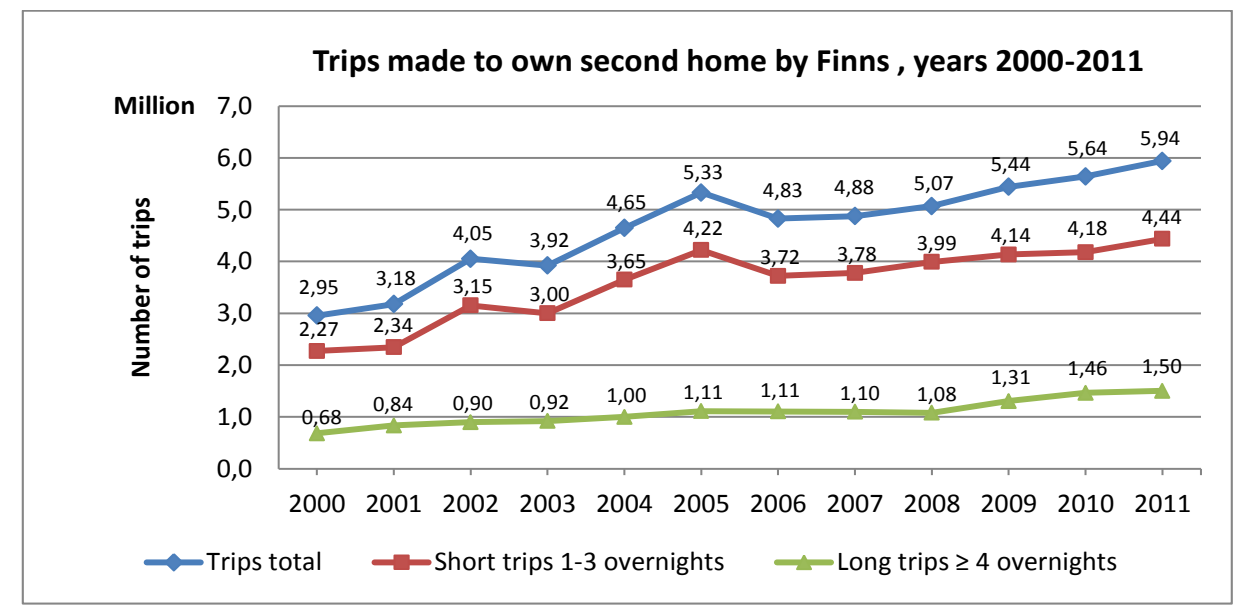

Fig. 7. Number of trips made by Finnish second home owners to own second home in years 2000-2011 Source: Official Statistics Finland, Finnish Travel, years 2000-2011. 


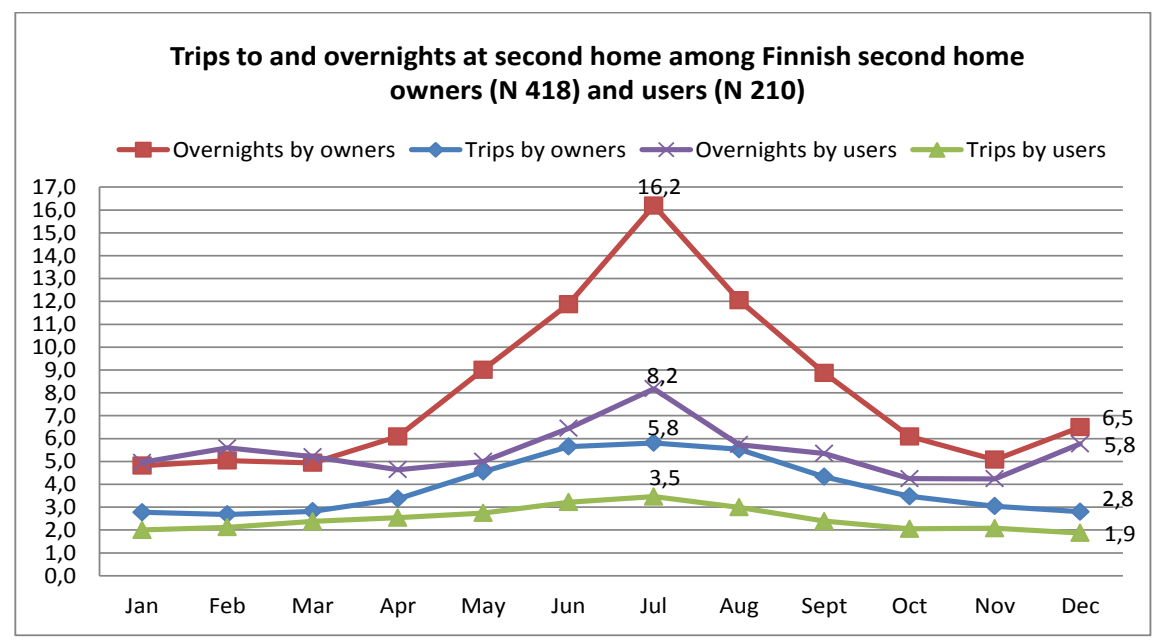

Fig. 8. Number of trips to and overnights at second home monthly among second owners ( $\mathrm{N} 418$ ) and regular users ( $\mathrm{N} 210$ ). Source: HbH Study 2012.

\section{Second home tourism weekends}

Travelling between home and second home weekends is a major and growing part of second home tourism. The so called 'weekend zone' describes the time-distance related to the willingness to travel to second home for a weekend (Hall \& Müller 2004b). A previous study indicates the patterns of long haul second home tourism and shows that the weekend zone among Helsinki metropolitan second home owners exceeds to 200-250 km of travel distance and around three hours of driving time (Hiltunen 2005; Pitkänen 2008). Results of the $\mathrm{HbH}$ Study allow analysing short haul second home tourism and show that the number of cottage trips is noticeably diminishing when the distance exceeds $50 \mathrm{~km}$ (Fig. 9). The high number of visits to nearby second homes is partly explained by the Finnish cultural tradition of sauna bathing at cottages. Most cottages definitely have a woodheated sauna (Periäinen 2006) and often summer evening visits to nearby second homes are made merely to have a sauna bath.

The weekend and the day travel zone of second home tourism applies to most urban centres. However, time-distance considerations are blurred when widening the scope and scale to the entire country. As was discussed earlier, metropolitan dwellers are ready to travel longer trips to rural second homes. Furthermore, the urban dwellers increasingly purchase second and even third homes in the tourist resorts of Lapland (Tuulentie 2007). A quarter (24\%) of all HbH Study respondents had access to two second homes and 5\% even to three. Lapland is now accessible also for a long weekend as second home owners and users reach the cottages and time-shares by plane, night train or night bus. This reshapes the weekend zone of second home tourism (Kauppila 2010) and leads to a rethink of distance decay effects in general as the 'distances' and 'zones' get elastic and stretchy features. In today's modern mobility environment, the spatio-temporalities of travel patterns become intricate and flexible depending on the travel mode, speed and time of the day (Hall 2005; Muller 2006).

\section{Means of travelling and accessibility}

The private car is far and away the most used means of transport when travelling to second home. A car enables flexible and convenient access from door to door and allows transporting the necessary belongings and equipment which guarantee the popularity of cars also in the future. The private car can be experienced as an extension of home with the car being personal space between primary and second home and, as such, more alluring than public transport (Sheller 2005; Urry 2007). Nowadays it is not unusual that families 


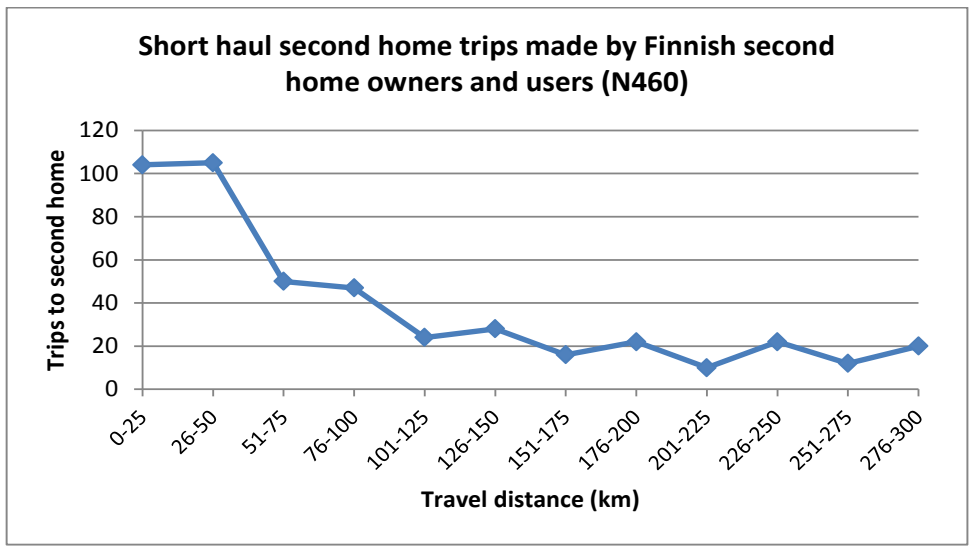

Fig. 9. Number of yearly second home trips made by Finnish second home owners and users when travel distance between home and second home is less than $300 \mathrm{~km}$ ( N 460). Source: HbH Study 2012. and relatives travel to the cottage with more than one car. According to Finnish national statistics $95 \%$ of all trips made to second homes are made by private cars with only $2 \%$ by train and $1 \%$ by bus (OSF 2012b). In the $\mathrm{HbH}$ Study $89 \%$ of those respondents who had regular access to a second home travelled the cottage trips by household's own car (Table 3). In a few households a leased car tied up with an employee contract was used. Rental cars were barely used however over $12 \%$ of the respondents indicated that they travel on board with a relative or friend. The respondents using a ride on cottage trips were mostly female $(76 \%)$ and quite often from single households (41\%).

The use of public transportation on the way to the second home is marginal but, nonetheless, according to $\mathrm{HbH}$ Study $6 \%$ used bus and $5 \%$ train on cottage trips (Table 3). The longer the trip the more bus and train were used. Whenever a boat was used on cottage trips, then most often a motorboat. In the archipelago region also public car ferries are used. Some of the long distance travellers used aeroplanes on cottage trips, but this was very seldom the case. Taxis were sometimes used, most likely as a connection to public transport. Bicycles are often used on second home trips when the cottage is located very close to home. Other means of transport mentioned on second home trips were walking, motor bike or moped, snowmobile or all-terrain vehicle.

While staying at the second home most respondents $(77 \%)$ used a private car for local shopping and personal trips. Bicycles (13\%) and boats $(13 \%)$ were also used fairly often for trips in second home surroundings. Some people made these trips by foot (5\%) but seldom by bus or mopeds, scooters or motorbikes ( $1 \%$ each). Very seldom (less than 1\%) were taxi, train, all-terrain-vehicles, snowmobiles or skies used for local trips in the second home community.

\section{Distance work and commuting from second home}

It is often thought that virtual mobility and distance work would reduce human physical mobility, however effects e.g. on commuting seem marginal (Helminen \& Ristimäki 2007). According to national statistics $5 \%$ of Finnish second home owners did distance work at second home in 2003 while in 2008 the amount had reached $10 \%$ (Nieminen 2010). Willingness to work distance thus seems to increase which indicate the trend of blurring work and leisure time. Distance work is getting more popular as, in ever more second homes, the standard of amenities are home like and Internet access available. The $\mathrm{HbH}$ Study 2012 results show that every fourth (26\%) second home had an Internet access.

The Internet connection however does not necessarily increase willingness to do distance work at second home. The clear majority $(86 \%)$ of the working respondents stated that no one in the household does daily work duties at second home. Only one percent did distance work regularly and $13 \%$ occasionally. Working by distance obviously depends on work tasks and ever more often the nature of work in information society 
Table 3. Means of transportation used during the trip from home to second home. Source: HbH Study 2012 (N 649).

\begin{tabular}{lclc}
\hline Means of transportation & $\%$ & Means of transportation & $\%$ \\
\hline Household own car & 89.1 & Taxi & 1.5 \\
Leasing car & 3.3 & Bus & 6.0 \\
Rental car & 0.2 & Train & 5.4 \\
On board with a car & 12.4 & Motor boat & 8.5 \\
Aeroplane & 1.1 & Rowing boat & 2.3 \\
& & Bicycle & 6.0 \\
\hline
\end{tabular}

would allow flexible work practices. However, it seems that among the second home owners and users the free-time spent at the cottage is mainly used for relaxing and getting mental distance from working life. Nevertheless, the share of occasional remote workers is likely to grow and blurring of work and leisure time expected to increase. Commuting to work is not very common among the working respondents as in the $\mathrm{HbH}$ Study only in $2 \%$ of working households someone commuted from second home regularly. However, infrequent commuting was much more popular as in every fifth $(20 \%)$ household a family member occasionally commuted to work from second home. Travel distance between home and second home affected the willingness to commute as whenever the cottage trip was less than $50 \mathrm{~km} \mathrm{4 \%}$ commuted regularly and $24 \%$ occasionally.

\section{The future use of second homes}

The HbH Study respondents were asked to evaluate the future use of second homes within the next five years. These study results indicate the mobility behaviour related to second home use in the near future. The majority of second home owners $(55 \%)$ and regular users $(68 \%)$ reckoned they would spend at least as much time at the cottage as present. Additional $22 \%$ of owners and $12 \%$ of users stated they would spend more time at the cottage than at present. Moreover as less than one percent of second home owners had made the decision of moving permanently to second home, it is apparent that physical mobility between home and second home will remain integral part of second home owners and users way of life. The future use of second homes is also in- fluenced by the regular users of whom $56 \%$ stated that they themselves or another member of the household will most likely inherit a second home. Many of these people thus form the next generation of second home owners and eventually continue the active mobile lifestyle.

A comparable survey to $\mathrm{HbH}$ Study was conducted in Sweden among second home owners (Müller et al. 2010). The survey results in Finland and Sweden show similar trends in second home tourism. Swedish second home owner households typically consist of middle aged couples who are relatively well educated and financially well off. A significant amount (39\%) of second home owners are pensioners and majority $(74 \%)$ lives in urban or suburban environments. More than $80 \%$ of second homes in Sweden are located in rural areas, most often in coastal or mountain regions. Some $15 \%$ of households own two second homes. Many (65\%) respondents believe that childhood sojourn in rural areas has contributed to their rural second housing today. Second homes are used actively during the summer season and most $(81 \%)$ respondents believe that within the next five years they will use the second home as often or more than at present. However, only $3 \%$ have definite plans to move to second home permanently nevertheless over $14 \%$ have considered migration. Nearly $63 \%$ of the respondents state that the second home will be passed to the next generation as inheritance. Since quite many (45\%) owner households live in detached houses the authors conclude that for many a rural second home is not necessarily a compensation but rather a complementing element in living and housing. Furthermore, the increasing use of second homes indicates that the boundaries and division between the two or multiple dwellings will become more fluid (Müller et al. 2010).

\section{Conclusions}

For more and more people, everyday life sphere consists of attachment to multiple meaningful places and travelling between them. This paper focused on physical mobility related to leisure oriented lifestyle and multiple dwelling, and studied how second home mobility is appearing and enacted in Finland. Spatial mobility patterns (locations, distribution, distances, flows) and social mobility practices (trips, means, usage, access) were studied. The nationwide GIS data analysis shows 
that spatial distribution of second homes in Finland follows well the landscape regions. Rural second homes are widespread and concentrate in the amenity rich regions of Lakeland, coastal areas and tourist centres of Lapland. Most second homes are located in secluded plots in forest surroundings of rural scattered areas by lakes and seashore. Travel distances to second homes differ depending on the population size and density of the urban region of origin. Distances to second homes are two to three times higher among urban dwellers living in the metropolitan region of Helsinki compared to cottagers living in provincial towns.

The findings of a questionnaire survey conducted among Finns in the autumn of 2012 (HbH Study $\mathrm{N}$ 1189) open up the present day mobility practices and behavioural patterns related to second home tourism in Finland. The ways, habits and means of physical second home mobility were studied. In this paper those survey respondents who had regular access to a second home at least once a year were scrutinised ( $\mathrm{N} 649,54 \%$ ). The two yearly peaks in second home trips and overnights, a major one in holiday month of July and a minor one during Christmas holidays, indicate the growing interest of year round use of cottages. Travelling between home and second home as well as the trips while staying at second home are predominantly made by private cars. Public transport is marginally used, however there are some second home owners and users who do use the more low carbon modes of transport, bus (6\%) and train (5\%). Having a car ride on board relatives and friends is common among carless female second home owners and users living in single households.

The study exposes well the mobility practices of the currently largest and most active cottager group, the retiring baby boomers. This relatively healthy and wealthy generation will also remain active cottagers in the near future. Second home culture is currently changing and second home owners and users appear increasingly to demand qualities and amenities of home life in second homes. Ever more often the second home is well equipped and over half of the respondents stated their cottage is fit for year round use. It also seems that the blurring of leisure and work is increasing among second home owners and users. According to the $\mathrm{HbH}$ Study an Internet access is available in a quarter of second homes and thus remote work is possible. However, the clear majority of working respondents stated that no one in the household does daily work duties at second home, nevertheless $13 \%$ does remote work occasionally.

Over half of the second home owners and users had previously lived in the countryside and also had childhood and youth experiences on rural cottage life. Often the cottage has been built in rural regions of family roots. However, despite the rural relations many second home owners and users have over the years developed strong place attachment to permanent living environment. This conclusion is supported by the survey result that very few $(1 \%)$ of second home owners have made the decision of moving permanently to second home. The family and other social relations both in urban and rural environments and attachment to two living environments have led to multiple place attachment and mobile lifestyle.

In this paper, second home related mobility was approached through a relational view and depiction of human geography. The paper highlights that spatial mobility patterns and social mobility practices related to second home tourism are reliant on and intertwined with many elements and processes of bio-physical and socio-cultural environments. Based on data analysis and previous literature these relationalities are identified and elucidated in figure 10. The phenomenon of second home mobility is related to natural and built environments, environmental governance and service provision. Furthermore, second home related mobility is interconnected to societal, technological and cultural changes as well as to social changes in second home owners' and users' lives. These relational elements and processes have affected the past development paths, present situation, and will also impact the future of second home mobility and tourism. The concluding analytical framework of relational time-space of second home related mobility illustrated in figure 10, is applicable also to other western societies with rural second home development.

Second home tourism and related mobile lifestyle are large and complex phenomena. Without rural second homes Finnish regional geography, rural landscapes, land use and transport system would most probably look rather different from today. Features of natural environment including climate and seasons, amenity rich landscapes and availability of suitable building land, form the basis for regional appearance of rural second homes and direct the streams of second home mobility. In Finland, the second home spatial distribution is particularly dependent on the natural water bodies 


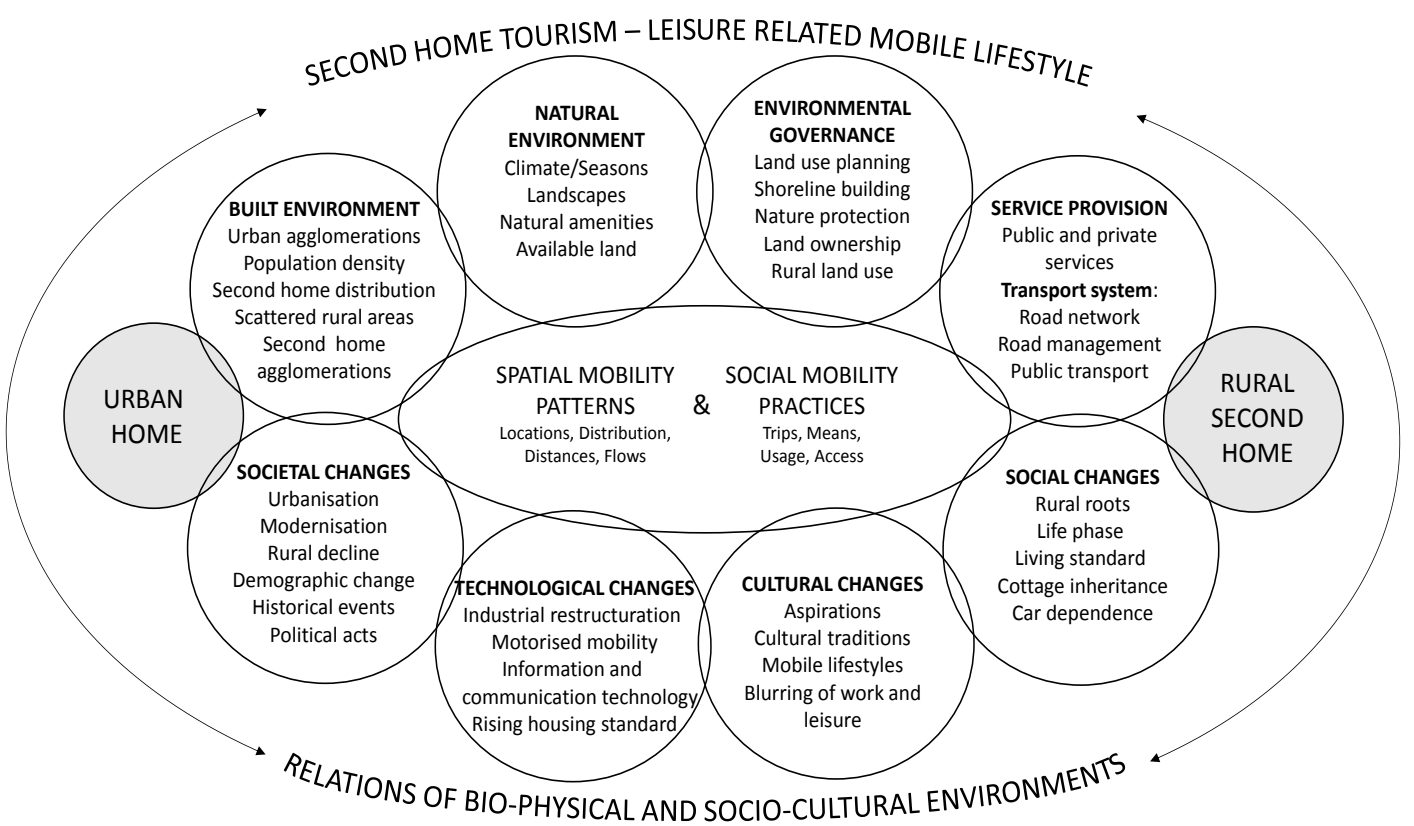

Fig. 10. Relational time-space of second home related mobility in-between urban and rural living environments. Identified relational elements and processes of bio-physical and socio-cultural environments interact with spatial mobility patterns and social mobility practices of second home tourism.

and length of shoreline. The mobility patterns and practices of second home tourism are also very much related to built environment, particularly to urban development and growth, size of urban area, and density of population which affect travel distances and travel time between urban home and rural second home. Second home rural development is governed by environmental regulations and land use planning system, in Finland especially by shoreline building regulations and protection of shore nature. Also land ownership and rural land use affect second home spatial development and related mobility. Provision of public and private services in communities and along the travel routes, and particularly the transport system including road network and year round road management affect the accessibility to second homes. Furthermore, travel mode and supply of public transport influence second home mobility patterns and practices.

Societal changes, including such megatrends as urbanisation, modernisation, rural restructuration and demographic change have affected second home tourism, distribution and mobility. Furthermore historical events and political decision making on different governmental levels have had an impact on second home tourism. Also technological changes especially motorised mobility, emergence of information society and rise in standard of second homes affect second home mobility and influence also cultural changes such as blurring of work and leisure and new activities at second homes. Some cultural traditions of second home tourism seem to prevail or change very slowly, e.g. the aspiration for solitude in natural surroundings. Also social changes influence second home owners' and users' mobility and enable people to make lifestyle choices related to second home tourism. Second home owners often have rural roots and are in the life phase of retirement. Increase in leisure time and living standard clearly affect second home use, related mobility and consumption patterns. Cottages are inherited by the new generations and especially well equipped second homes close to urban centres will remain popular. In relational respect second home owners and users en- 
act and perform their lifestyle in the spatial continuum of urban and rural environments. Combining the different housing environments and physical frequent travelling between the places is thereby a significant part of their everyday life and lifestyle. Second home mobility is also very much dependent on private cars, which is one of the key challenges considering the sustainable future of second home tourism.

\section{The future of second home related mobility}

The longing to nature and solitude surroundings has been attracting Finnish urban dwellers to rural second homes already for over two centuries. This in the beginning distinctively elite form of tourism has become a mass phenomenon from the 1950s on. Today the vast majority of second home owners and users travel the cottage trips by private cars and motorised urban-rural mobility plays a significant role in their lifestyle. Yet will the physical mobility between home and second home increase or conversely decrease in the future? Current tendency is the growth in mobility due to various societal, social and environmental reasons. The ever continuing urbanisation, hectic urban life and demanding work tasks, all lead to growing yearn for relaxation and the need to have rest from daily life duties. For many urban dwellers, rural second home life offers the desired recreation and alternation. Also leisure time is increasing especially among the retirees who are active cottagers.

Increase in economic growth, households' disposable income and family prosperity may lead to growing interest in investing and purchasing second homes. New second homes are today built for year round use and old ones renovated to meet the requirements of modern life. The rise in floor space and standard of second homes enable to spend more time at the cottage and lead to increase in second home use, also among the younger generations. The high season of second home tourism is getting longer as a result of better vehicles and accessibility to second homes. Also international second home demand and crossing borders increase the total mobility volume of second home tourism (Pitkänen 2011b; Lipkina et al. 2014). In the long run climate change is expected to engender the warming of climate in southern Finland, which will extend the high season of second home tourism (Jylhä et al. 2010).

Congestion and high demand for second homes in the urban green belt induce expanding pressure to build new cottages in unbuilt rural areas of urban hinterlands. Also ever more second homes are being inherited and especially those located close to urban centres remain desired. Short haul urbanrural second home tourism seems thus to be a persistent trend however also long distance second home travelling is increasing. From an environmental point of view the growth of short visits is ecologically more unsustainable than if second home owners would undertake longer lasting sojourns less frequently (Lahti 2010).

The growth in second home use, stock, trips and distances indicates the increase in second home mobility. There are however ongoing processes and future prospects in society which may as well decrease the mobility. These include considerable rise in petrol prices, growing environmental awareness, demand for other tourism and leisure activities and alternatives for second home ownership such as time-shares and rental holiday cottages leading to less trips and more eco efficient use of second homes. Also demographic development makes a key trend factor in the mobility volume of second home tourism. The younger urbanised generations may be less interested in rural cottage life and prefer other leisure activities. Also planning and building of peaceful and green urban residential housing environments and new areas of allotment garden cottages may decrease the need to seek recreational alternation in rural areas (Lahti 2010). On the other hand, modern second home life may well increase the popularity of second home tourism among the younger generations. Better telecommunication networks and growing interest in doing distance work at second homes might increase the overnights and periods spent at second homes. Consequently, the longer stays may decrease mobility between home and second home but on the other hand increase local mobility in second home region as daily trips for purchasing goods and services are likely to increase. Telecommunication and computer applications also enable video surveillance and remote steering of technological systems in second homes. Increase in popularity of such new technologies may reduce the need to do check-up visits at second home outside the high season of second home tourism.

Even though the private car is the most used mode of transport on cottage trips, the near future will show whether public transportation and carpooling become more popular among second home owners and users due to population ageing and potential environmental awareness. However, 
for such prospects wide and unhindered public transport supply would be needed as well as low price tickets and flexible feed transportation along the travel chains. It is therefore presumed that the private car will remain the most popular means of travelling between home and second home.

\section{ACKNOWLEDGEMENTS}

The authors wish to thank the two anonymous referees and professors Jarmo Kortelainen and C. Michael Hall for their valuable comments. Special thanks to Czesław Adamiak for non-response analysis of the $\mathrm{HbH}$ Study and Kati Pitkänen for comments and collegial support. The paper was written during the research project Homes beyond homes - Multiple dwelling and everyday living in leisure spaces, funded by the Academy of Finland (SA 255424).

\section{REFERENCES}

Adey P 2010. Mobility. Routledge, London.

Anttila A-H 2008. Mökkeily. In Häggman K, Kuisma M, Markkola P \& Pulma P (eds). Suomalaisen arjen historia, 4. Hyvinvoinnin Suomi, 177-183. WSOY, Helsinki.

Bendix R \& Löfgren O 2007. Double homes, double lives? Ethnologia Europaea 37: 1-2, 7-15.

Butler R 2004. Geographical research on tourism, recreation and leisure: origins, eras and directions. Tourism Geographies 6: 2, 143-162. http://dx.doi.org/10.1080/ 1461668042000208453.

Cloke P 2006. Conzeptualizing Rurality. In Cloke P, Mardsen T \& Mooney P (eds). The Handbook of Rural Studies, 18-29. Sage, London.

Creswell JW 2003. Research design: qualitative, quantitative and mixed methods approaches. Sage, Thousand Oaks.

Cresswell T 2006. On the move. Mobility in the modern western world. Routledge, New York.

Cresswell T, Holloway R \& Merriman P 2010. Geographies of Mobilities: Practices, Spaces, Subjects. Ashgate, Farnham.

Eriksson P \& Kovalainen A 2008. Qualitatitive methods in business research. Sage, London.

Gallent N, Mace A \& Tewder-Jones M 2005. Second homes: European perspectives and UK policies. Ashgate, Chippenham.

Granö JG 1929. Maantieteelliset alueet. In Suomen kartasto 1925, 111-122. Suomen Maantieteellinen Seura \& Otava, Helsinki.

Gustafson P 2006. Place attachment and mobility. In Mclntyre N, Williams D \& McHugh K (eds). Multiple dwelling and tourism: negotiating place, home and identity, 17-31. Cabi,Wallingford.
Haldrup M 2009. Second homes. In Kitchin R \& Thrift N (eds). International encyclopedia of human geography, 50-55. Elsevier, Amsterdam.

Hall CM 2005. Tourism: rethinking the social science of mobility. Pearson, Harlow.

Hall CM \& Müller DK 2004a (eds). Tourism, mobility and second homes: between elite landscape and common ground. Aspects of tourism 15. Channel View Publications, Clevedon.

Hall CM \& Müller DK 2004b. Introduction: second homes, curse or blessing? Revisited. In Hall CM \& Müller DK (eds). Tourism, mobility and second homes: between elite landscape and common ground, 3-14. Channel View Publications, Clevedon.

Hall CM, Müller DK \& Saarinen J 2009 (eds). Nordic tourism: issues and cases. Channel View Publications, Clevedon.

Hall CM \& Page SJ 2006. The geography of tourism and recreation. Environment, place and space. Routledge, London.

Halseth G 2004. The 'cottage' privilege: increasingly elite landscapes of second homes in Canada. In Hall CM \& Müller DK (eds). Tourism, mobility and second homes: between elite landscapes and common ground, 35-54. Channel View Publications, Clevedon.

Healey P 2007. Urban Complexity and Spatial Strategies: towards a relational planning of our times. The RTPI Library Series. Routledge, Abingdon.

Helminen V \& Ristimäki M 2007. Relationships between commuting distance, frequency and telework in Finland. Journal of Transport Geography, 15: 5, 331342.

http://dx.doi.org/10.1016/j.jtrangeo.2006.12.004.

Helminen V, Nurmio K, Rehunen A, Ristimäki M, Oinonen K, Tiitu M, Kotavaara O, Antikainen H \& Rusanen J 2013. Kaupungin-maaseudun alueluokitus. Paikkatietomuotoisen alueluokituksen muodostamisperiaatteet. Suomen ympäristökeskus SYKE.<http:// www.y m p a ris to.f i / down l o a d / noname/\% 7B 43BAC242-6890-4CE9-B17AC2167D17B674\%7D/76113>1.7.2013.

Hiltunen MJ 2005. Liikkuminen mökille. In Pitkänen K \& Kokki R (eds). Mennäänkö mökille? Näkökulmia pääkaupunkiseutulaisten vapaa-ajan asumiseen Järvi-Suomessa, 60-87. University of Joensuu, Savonlinna Institute for Regional Development and Research, Publications 11.

Hiltunen MJ 2009. Second Homes in Finland. In Hall CM, Müller DK \& Saarinen J (eds). Nordic Tourism. Issues and Cases, 185-188. Channel View Publications, Bristol.

Hiltunen MJ, Pitkänen K, Vepsäläinen M \& Hall CM 2013. Second home tourism in Finland: current trends and eco-social impacts. In Roca Z (ed). Second home tourism in Europe: lifestyle issues and policy responses, 165-198. Ashgate, Farnham.

Hinchliffe S 2007. Geographies of nature: societies, environments, ecologies. Sage, Los Angeles. 
HLT 2012. Henkilöliikennetutkimus 2010-2011, National travel survey. Finnish TransportAgency. <http:// www2.liikennevirasto.fi/julkaisut/pdf3/lr_2012_henkiloliikennetutkimus_web.pdf> 28.1.2013.

Jylhä K, Tuomenvirta H, Ruosteenoja K, Niemi-Hugaerts H, Keisu K \& Karhu JA 2010. Observed and projected future shifts of climate zones in Europe and their use to visualize climate change information. Weather, Climate, and Society 2: 2, 148-167. http://dx.doi.org/10.1175/2010WCAS1010.1.

Kauppila P 2010. Resorts, second home owners and distance: a case study in Northern Finland. Fennia 188: 2, 163-178.

Krohn A 1991. Elämän lomassa: suomalaisen loman historiaa. Lomaliitto, Helsinki.

Lahti P 2010. Mökkiliikenteen energia- ja ekotehokkuus. In Rytkönen A \& Kirkkari A-M (eds). Vapaa-ajan asumisen ekotehokkuus, 64-88. Suomen ympäristö 6. Ministry of the Environment, Helsinki.

Larsen J, Urry J \& Axhausen K 2006. Mobilities, networks, geographies. Aldershot, Ashgate

Leinonen R, Kauppila P \& Saarinen J 2007. Suomen matkailun aluerakenne 2005. Matkailun edistämiskeskus MEK A: 155. <http://www.mek.fi/ wp-content/uploads/2013/04/A155-Suomenmatkailun-aluerakenne-2005_Raportti.pdf $>$ 25.11.2013

Lipkina O, Tuulentie S \& Pitkänen K 2014. Do borders matter? Norwegian and Russian second home owners' relation to their leisure places in Finland. Journal of Borderlands Studies, submitted.

Lithander J, Tynelius U, Malmsten P, Råbock I \& Fransson E 2012. Rural Housing - Landsbygdsboende i Norge, Sverige och Finland. Tillväxtanalys, Rapport 05. Östersund. Nordic Council of Ministers. <http://www.tillvaxtanalys.se/do wnload/18.56 ef093c139bf3 ef 89029 cb/1349864058705/Rapport_2012_05.pdf $>$ 20.11.2013.

Löfgren O 1999. On holiday. A history of vacationing. University of California Press, Berkeley.

Marjavaara R 2008. Second home tourism: the root to displacement in Sweden. Doctoral thesis, Umeå universitet, Kulturgeografiska institutionen. GERUM 2008: 1.

Massey D 2005. For Space. Sage, London.

McIntyre N, Williams D \& McHugh K 2006 (eds). Multiple dwelling and tourism: negotiating place, home and identity. Cabi, Wallingford.

Mclntyre N 2009. Re-thinking amenity migration: integrating mobility, lifestyle and social- ecological systems. Die Erde 140: 3, 229-250.

Merriman P 2012. Mobility, space and culture. Routledge, Abingdon.

Ministry of Environment 2005. Rantojen maankäytön suunnittelu. Ympäristöopas 120, Alueiden käyttö. Ympäristöministeriö, Helsinki.

Murdoch J 2006. Post-structuralist geography: a guide to relational space. Sage, London.
Müller DK 2006. The attractiveness of second home areas in Sweden: a quantitative analysis. Current Issues in Tourism 9: 4, 335-350. http:// dx.doi.org/10.2167/cit269.0.

Müller DK 2007. Introduction. Second homes in the Nordic Countries. Between common heritage and exclusive commodity.

Scandinavian Journal of Hospitality and Tourism 7: 3, 193-201.

http://dx.doi.org/10.1080/15022250701300272.

Müller DK 2013. Progressing second home research: a Nordic perspective. Scandinavian Journal of Hospitality and Tourism 13: 4, 273-280. http:// dx.doi.org/10.1080/15022250.2013.866303.

Müller DK \& Hall CM 2004. The future of second home tourism. In Hall CM \& Müller DK (eds). Tourism, mobility and second homes: between elite landscape and common ground, 273-278. Channel View Publications, Clevedon.

Müller DK \& Hoogendoorn G 2013. Second homes: curse or blessing? A review 36 years later. Scandinavian Journal of Hospitality and Tourism 13: 4, 353-369. http://dx.doi.org/10.1080/15022250.20 13.860306 .

Müller DK, Nordin U \& Marjavaara R 2010. Fritidsboendes relationer till den svenska landsbygden. Resultat av en enkät bland svenska fritidshusägare 2009. GERUM Kulturgeografisk arbetsrapport 2010-04-15. Kulturgeografiska institutionen, Umeå Universitet.

Nieminen M 2010. Kesämökkibarometri 2009. Työja elinkeinoministeriö, Alueiden kehittäminen, 12 . <http: //www.tem.fi/files/27185/ tem_12_2010_web.pdf> 13.5.2013.

Nouza M, Ólafsdóttir R \& Müller DK 2013. A new approach to spatial-temporal development of second homes: Case study from Iceland. Scandinavian Journal of Hospitality and Tourism 13: 1, 2037. http://dx.doi.org/10.1080/15022250.2013.76 4512 .

OSF 2012a. Official Statistics of Finland. Dwellings and housing conditions 2011. Housing 2012. <http://www.tilastokeskus.fi/til/asas/2011/01/ asas_2011_01_2012-10-24_en.pdf>.3.5.2013.

OSF 2012b. Official Statistics of Finland. Finnish Travel 2011. Transport and Tourism 2012. <http:// wWw.stat.fi/til/smat/2011/smat_2011_2012-0530_en.pdf> 3.5.2013.

OSF 2013a. Official Statistics of Finland. Buildings and free-time residences 2012. Housing 2013. <ht t p : / / stat.fi/til/rakke/2012/ rakke_2012_2013-05-24_en.pdf>6.6.2013.

OSF 2013 b. Official Statistics of Finland. Kotitalouksien käytettävissä olevat rahatulot vuonna 2011. <http://www.stat.fi/til/tjt/2011/03/ tjt_2011_03_2013-04-10_kat_001_fi.htm/ > 28.6.2013.

Overvåg K 2009a. Second homes in eastern Norway: from marginal land to commodity. Doctoral theses at NTNU, 238. Norwegian University of Sci- 
ence and Technology, Faculty of Social Sciences and Technology Management.

Overvåg K 2009b. Second homes and urban growth in the Oslo area, Norway. Norsk Geografisk Tidskrift - Norwegian Journal of Geography 63: 3, 154-165. http://dx.doi.org/10.1080/00291950903238974.

Paris C 2010. Affluence, mobility, and second home ownership. Routledge, New York.

Periäinen K 2006. The summer cottage: a dream in the Finnish forest. In Mclntyre N, Williams D \& McHugh K (eds). Multiple dwelling and tourism: negotiating place, home and identity, 103-113. Cabi, Wallingford.

Pirie GH 2009. Distance. In Kitchin R \& Thrift N (eds). International encyclopedia of human geography, 242-251. Eelsevier, Amsterdam.

Pitkänen K 2008. Second-home landscape: The meaning(s) of landscape for second-home tourism in Finnish Lakeland. Tourism Geographies 10: 2, 169-192.

http://dx.doi.org/10.1080/14616680802000014.

Pitkänen K 2011a. Mökkimaisema muutoksessa: kulttuurimaantieteellinen näkökulma mökkeilyyn. Doctoral Thesis. University of Eastern Finland, Dissertations in Social Sciences and Business Studies No 31. <http://urn.fi/URN:ISBN:978-952-61-0605-2>

Pitkänen K 2011b. Contested cottage landscapes: Host perspective to the increase of foreign second home ownership in Finland 1990-2008. Fennia 189: 1, 43-59.

Pitkänen K \& Vepsäläinen M 2008. Foreseeing the future of second home tourism: The case of Finnish media and policy discourse. Scandinavian Journal of Hospitality and Tourism 8: 1, 1-24. http://dx. doi.org/10.1080/15022250701880729.

Raivo P 2002. The Finnish landscape and its meanings. Fennia 180: 1-2, 89-98.

Roca Z 2013 (ed). Second home tourism in Europe: lifestyle issues and policy responses. Ashgate, Farnham.

Rolshoven J 2007. The temptations of the provisional: multilocality as a way of life. Ethnologia Europaea 37: 1-2, 17-25.

Sheller M \& Urry J 2006. The new mobilites paradigm. Environment and Planning $A$ 38: 2, 207-226. http://dx.doi.org/10.1068/a37268.
Sheller M 2005. Automotive Emotions: Feeling the Car. In Featherstone M, Thrift N \& Urry J (eds). Automobilities, 221-242. Sage, London.

Shellito BA 2006. Second-home distributions in the USA's Upper Great Lakes States: analysis and implications. In Mclntyre N, Williams D \& McHugh K (eds). Multiple dwelling and tourism: negotiating place, home and identity, 194-206. Cabi, Wallingford.

Thrift N 2003. Space: The fundamental stuff of human geography. In Holloway SL, Rice SP \& Valentine G (eds). Key concepts in geography, 95-107. Sage, Trowbridge/Wiltshire.

Tjørve E, Flognfeldt T \& Calf Tjørve KM 2013. The effects of distance and belonging on second-home markets. Tourism Geographies 15: 2, 268-291. http://dx.doi.org/10.1080/14616688.2012.726264.

Tress G 2002. Development of second-home tourism in Denmark. Scandinavian Journal of Hospitality and Tourism 2: 2, 109-122. http://dx.doi.org/10.1080/15022250216289.

Tuulentie S 2007. Settled tourists: Second homes as a part of tourist life stories. Scandinavian Journal of Hospitality and Tourism 7: 3, 281-300. http:// dx.doi.org/10.1080/15022250701300249.

Urry J 2007. Mobilities. Polity Press, Cambridge.

Vepsäläinen M \& Rehunen A 2009. Lomalla kylän lomassa? Kylämökkeilyn rajaaminen, nykytila ja muutokset. Matkailututkimus 5:2, 43-56.

Vepsäläinen M \& Pitkänen K 2010. Second home countryside. Representations of the rural in Finnish popular discourses. Journal of Rural Studies 26: 2, 194-204. http://dx.doi.org/10.1016/j. jrurstud.2009.07.002.

Virtanen PV 2006. Asutustoiminta itsenäisessä Suomessa. Maankäyttö 1: 6-11.

Vuori O 1966. Kesähuvilanomistus Suomessa. Annales Universitatis Turkuensis, Series C, Tom. 3, Turku.

Vuoristo K-V \& Vesterinen N 2009. Lumen ja suven maa: Suomen matkailumaantiede. WSOYpro Oy, Helsinki.

Whatmore S 2002. Hybrid geographies: natures, cultures, spaces. Sage, Thousand Oaks.

Woods M 2011. Rural. Routledge, London. 